\title{
Differences in soft-sediment macrobenthic assemblages invaded by Caulerpa taxifolia compared to uninvaded habitats
}

\author{
Justin G. McKinnon ${ }^{1}$, Paul E. Gribben ${ }^{2,4}$, Andrew R. Davis ${ }^{1}$, Dianne F. Jolley ${ }^{3}$, \\ Jeffrey T. Wright ${ }^{1,5, *}$

\begin{abstract}
${ }^{2}$ Centre for Marine Biofouling and Bio-Innovation and School of Biological, Earth and Environmental Sciences, University of New South Wales, Sydney 2052, Australia

${ }^{3}$ GeoQuest, School of Chemistry, University of Wollongong, Wollongong 2522, Australia

${ }^{4}$ Present address: Institute of Water and Environmental Management, and Department of Environmental Sciences, University of Technology, Sydney 2007, Australia

${ }^{5}$ Present address: National Centre for Marine Conservation and Resource Sustainability, Australian Maritime College, The University of Tasmania, PO Box 986, Launceston 7250, Australia
\end{abstract} \\ ${ }^{1}$ Institute for Conservation Biology and School of Biological Sciences, University of Wollongong, Wollongong 2522, Australia
}

\begin{abstract}
Caulerpa taxifolia is a habitat-forming green alga that has invaded several temperate regions worldwide. Although C. taxifolia covers large areas of soft-sediment habitat, little is known about its effects on soft-sediment invertebrate assemblages. We compared soft-sediment macroinvertebrate assemblages in 2 estuaries in southeastern Australia invaded by $C$. taxifolia to examine 2 main predictions: (1) areas covered with $C$. taxifolia will have different assemblages compared to unvegetated sediment because infauna are inhibited but epifauna are facilitated, and (2) areas with C. taxifolia will have different assemblages compared to those with native seagrasses (Halophila ovalis and Zostera capricorni) because infauna are inhibited but epifauna are not. Multidimensional scaling and ANOSIM showed differences in invertebrate assemblages between all habitats. In C. taxifolia, infauna were less abundant and epifauna were more abundant compared to unvegetated sediment. However, when compared to native seagrasses, epifauna in C. taxifolia were more abundant than in $H$. ovalis in one estuary but less abundant than in $Z$. capricorni in another estuary, while infauna in C. taxifolia were less abundant than in both seagrass species. The consistently low infaunal abundance in C. taxifolia, irrespective of infaunal feeding mode, suggests C. taxifolia impacts infauna generally. Examination of environmental factors potentially responsible for the low abundance of infauna indicated that differences in redox potential (and associated chemical changes) may explain patterns in abundance of infauna among habitats. Our findings indicate that invasion by $C$. taxifolia causes important changes to soft-sediment macroinvertebrate assemblages and suggest that infauna may be particularly vulnerable to invasion because of changes to sediment chemistry.
\end{abstract}

KEY WORDS: Caulerpa taxifolia - Community composition - Ecosystem engineers - Facilitation · Habitat-forming species · Inhibition · Invasion biology · Seagrass

\section{INTRODUCTION}

Marine and estuarine habitat-forming invasive species have major effects on native communities. In soft-sediment marine systems, they modify a range of abiotic factors, including water flow, food availability, the deposition of organic material and sediment chemistry, which all have potentially important implications for native fauna (Posey 1988, Chisholm \& Moulin 2003, Neira et al. 2005, 2006, Hacker \& Dethier 2006). However, their effects on soft-sediment fauna are complex and appear to depend on the habitat invaded (unvegetated vs. native habitat-forming species) and whether fauna live in or above the sediment (infauna vs. epifauna). Compared to unvegetated sediment, habitat-forming invasive species typically have a higher abundance of epifauna, but a 
lower abundance of certain infaunal species or functional groups and, consequently, very different faunal assemblages (Crooks 1998, Crooks \& Khim 1999, Hedge \& Kriwoken 2000, Neira et al. 2005, 2006, Levin et al. 2006). An exception to this general pattern is the invasive seagrass Zostera japonica, which had a higher abundance of infauna compared to unvegetated sediment (Posey 1988). Compared to native habitat-forming species, invasive habitat-forming species have a similar abundance of epifauna and infauna, leading to similar faunal assemblages (Hedge \& Kriwoken 2000), or assemblages differing in some species or functional groups, which leads to different faunal assemblages (e.g. fewer infaunal surface feeders; Neira et al. 2005, Levin et al. 2006). The reasons why some infauna are negatively affected by habitatforming invasive species is unresolved, but they may relate to changes to the sediment quality following invasion. For example, sediment pore water sulphides and anoxia have been linked to poor survivorship of infauna beneath invasive Spartina spp. (Neira et al. 2006).

Caulerpa taxifolia is a habitat-forming green alga considered one of the worst 100 invasive species in the world (Lowe et al. 2000). It has invaded several temperate regions worldwide where it covers large areas of soft-sediment habitat (Meinesz et al. 2001, Creese et al. 2004, Anderson 2005). C. taxifolia spreads rapidly across unvegetated sediment, reaches very high densities, forms a thick, vegetated mat above the sediment (Wright 2005, Wright \& Davis 2006) and modifies the chemical and physical properties of sediments and water (Chisholm \& Moulin 2003, Gribben et al. 2009). C. taxifolia has variable impacts on native seagrass in the Mediterranean (Ceccherelli \& Cinelli 1997, Ceccherelli \& Sechi 2002), while seagrass beds in southeastern Australia do not appear to be readily invaded (Glasby \& Creese 2007). Consequently, invaded estuaries in southeastern Australia may become a mosaic of different habitat-forming macrophytes (invasive C. taxifolia and native seagrasses) and unvegetated sediment. Although C. taxifolia covers large areas of soft-sediment habitat and fish assemblages differ between $C$. taxifolia and native seagrass (York et al. 2006), with the exception of studies of a dominant estuarine bivalve species in southeastern Australia (Gribben \& Wright 2006a,b, Wright et al. 2007, Wright \& Gribben 2008, Gribben et al. 2009), little is known about how soft-sediment macroinvertebrates are affected by $C$. taxifolia invasion.

Invasion of estuaries by Caulerpa taxifolia may have 2 main impacts on soft-sediment macrobenthic essemblages. First, compared to unvegetated sediment, $C$. taxifolia may have very different assemblages because epifauna are facilitated by the addition of structure, but infauna are inhibited by changes to the sediment. Second, compared to native seagrasses, C. taxifolia may have different assemblages, because infauna are inhibited by changes to the sediment even though epifauna are not. We tested our predictions by examining patterns of macrobenthic invertebrate assemblages associated with $C$. taxifolia, 2 seagrass species and unvegetated sediment at sites in 2 estuaries in southeastern Australia. Specifically, we asked the following questions. (1) Do macrobenthic invertebrate assemblages differ among habitats and sites? (2) Do the total species richness, total faunal abundance, epifaunal abundance and infaunal abundance differ among habitats and sites? (3) Does the abundance of different feeding groups differ among habitats and sites? (4) Do environmental characteristics potentially important for fauna (sediment properties and water quality) differ among habitats and sites, and are they correlated with any differences in faunal assemblages?

\section{MATERIALS AND METHODS}

Study organisms and locations. In southeastern Australia, Caulerpa taxifolia has invaded 14 estuaries since its discovery in 2000. Our study was conducted from May to June 2006 in 2 of these estuaries where C. taxifolia is locally abundant (St Georges Basin, $35^{\circ} 11^{\prime} \mathrm{S}$, $150^{\circ} 36^{\prime} \mathrm{E}$, and Burrill Lake, $\left.35^{\circ} 24^{\prime} \mathrm{S}, 150^{\circ} 27^{\prime} \mathrm{E}\right)$. C. taxifolia was first described in Burrill Lake in 2001 and in St Georges Basin in 2004 (Creese et al. 2004). As of June 2006, approximately $0.1 \mathrm{~km}^{2}(<1 \%)$ of the softsediment benthos of St Georges Basin and approximately $0.5 \mathrm{~km}^{2}(\sim 12 \%)$ of the soft-sediment benthos of Burrill Lake were affected by C. taxifolia. In St Georges Basin, C. taxifolia co-occurs primarily with the seagrass Halophila ovalis and unvegetated sediment. In Burrill Lake, C. taxifolia co-occurs primarily with the seagrass Zostera capricorni while unvegetated sediment only occurred in very small patches $(<1 \mathrm{~m}$ diameter $)$ at invaded sites and appeared to have been caused by disturbance to $Z$. capricorni. Consequently, we did not sample unvegetated habitat in Burrill Lake. Z. capricorni and $H$. ovalis differ in ways that may be important for invertebrate assemblages: Z capricorni has long, densely packed leaves and thick rhizomes, while $H$. ovalis has short leaves and thin rhizomes (Edgar 2000). The greater above- and below-ground biomass of $Z$. capricorni might influence sediment properties or water flow (e.g. Reusch \& Williams 1999). In St Georges Basin, Z. capricorni was sparse or absent from the sites invaded by C. taxifolia.

Sediment properties and water quality. Differences in sediment redox potential, $\mathrm{pH}$ and silt fraction among habitats were determined using replicate $(\mathrm{N}=5$ per habitat and site) sediment cores collected from 1 to $1.5 \mathrm{~m}$ water depth at 2 sites in St Georges Basin (Smiths Bay and Pats Bay) and Burrill Lake (Kings 
Point and Broadwater). Samples were collected from patches of approximately $100 \%$ cover of each habitat at each site. In St Georges Basin, cores were taken to a depth of $20 \mathrm{~cm}$ using a stainless steel wedge (dimension of the top of the wedge: $20 \times 10 \mathrm{~cm}$ ), which gave a vertical profile of the core from which measurements could be taken. Three redox readings were taken per core at profile depths of $0-2,2-5$ and $5-10 \mathrm{~cm}$. We sampled a sediment profile to understand changes in redox potential with sediment depth as this provides insights into changes in chemistry within the sediment. For $\mathrm{pH}$, a single reading was taken between 2 and $5 \mathrm{~cm}$ depth as the probe was too large to sample the depth profile. In Burrill Lake, the sediment was a thin layer $(\sim 5 \mathrm{~cm})$ overlying very coarse shell grit and the wedge corer could not be pushed in deeply enough to obtain a depth profile. Instead, a shovel was used to carefully scoop up sediment with care taken to ensure the core was kept intact. The presence of the rhizoids or rhizomes maintained the integrity of the profile. Subsequently, both redox potential and $\mathrm{pH}$ were only measured once (between 2 and $5 \mathrm{~cm}$ depth) in sediment cores from Burrill Lake. Redox potential was measured using a Metrohm AG 9109 Herisau Combined Pt-wire electrode, with an $\mathrm{Ag} / \mathrm{AgCl}$ reference electrode. The instrument was calibrated using Orion Application Solution ORP Standard 967961, and all redox readings were corrected for $\mathrm{EH}_{\mathrm{Ref}}=-210 \pm 3 \mathrm{mV}$, i.e. reported redox potentials are versus that of the hydrogen electrode, $\mathrm{EH}_{0}=0 \mathrm{mV}$. A Sensorex Combination $\mathrm{pH}$ electrode $(450 \mathrm{C})$ with a Rex $\mathrm{pH}$ meter (Model pH $\beta$-4) was used for all $\mathrm{pH}$ measurements and was calibrated against standardised pH 4 and 7 NIST buffers before use. The electrode was rinsed with deionised water before and after each measurement. Instruments were recalibrated after sampling each habitat (i.e. after 5 replicate cores). The silt fraction in the sediment samples was determined from the top $5 \mathrm{~cm}$ of the same cores used to measure redox and $\mathrm{pH}$. Initially, laser diffraction using an x-ray diffraction instrument (Mastersizer, Malvern Instruments) of sediment samples $(50 \mathrm{ml})$ was done. Following this, subsamples (of approximately $1 \mathrm{~g}$ ) were taken from each sample using thief sampling (Gale \& Hoare 1991). Samples were then added to a tap water dispersant and the proportion of silt and clay was determined.

For consistency, water measurements in all habitats were taken between 10 and $15 \mathrm{~cm}$ above the sediment. The dissolved oxygen (DO) of water was measured using a YSI 95 DO and temperature microelectrode array, Model No. 95/25 Ft, and water pH, salinity and temperature were measured using a Yeo-Kal multiparameter water instrument, YSI $460 \mathrm{MSD}$.

Macrobenthic invertebrate assemblages. To compare differences in macrobenthic invertebrate assem- blages among habitats, faunal core samples were collected from 1 to $1.5 \mathrm{~m}$ water depth using a handheld, stainless steel corer (22 cm diameter, $10 \mathrm{~cm}$ length) at the 2 sites in St Georges Basin (Smiths Bay and Pats Bay) and in Burrill Lake (Kings Point and Broadwater). Replicate ( $\mathrm{N}=10$ per habitat) cores were collected from intermingling patches of Caulerpa taxifolia, Halophila ovalis and unvegetated sediment at both sites in St Georges Basin, and in C. taxifolia and Zostera capricorni at both sites in Burrill Lake. All cores were collected from patches of approximately $100 \%$ cover in the habitat sampled. Core contents were sieved on site through a sieve of $1 \mathrm{~mm}$ mesh size. After sieving, all invertebrates were placed into individually labelled $\mathrm{Zi}$ plock bags. Samples were fixed in 5\% formalin and stored in $70 \%$ ethanol for further identification.

Except for polychaetes and some other rare taxa, which were only identified to family level, most invertebrates were identified to species level and counted. Taxa were further defined by (1) whether they were epifaunal or infaunal and (2) their feeding mode (suspension feeders, surface detritus feeders, sub-surface deposit feeders and predators/omnivores; according to Fauchald \& Jumars 1979) to analyse potential effects of Caulerpa taxifolia invasion on specific functional groups. Although other studies have placed suspension feeders and surface deposit feeders into the same group (Neira et al. 2005, Levin et al. 2006), we analysed these groups separately, as their food sources (i.e. suspended material vs. detritus or microorganisms in the sediment) and feeding functions are different. We also placed Anadara trapezia adults and recruits into separate categories for both multivariate analyses and univariate analyses of epifaunal abundance and infaunal abundance, as they change their living arrangements with ontogeny (i.e. postsettlement recruits are epifaunal and adults are infaunal; Gribben \& Wright 2006a). This distinction was not made for analysis of species richness.

Statistical analyses. Because different habitats were sampled at each estuary, estuaries were analysed separately. Two-factor analyses of variance (ANOVA) with the factors Habitat (fixed) and Site (random) were used to determine differences in sediment silt fraction, $\mathrm{pH}$ and redox. In St Georges Basin, redox potential data for Pats Bay could not be collected due to a malfunctioning probe. Consequently, redox in Smiths Bay was analysed with a 3-factor ANOVA with Habitat (fixed), Block (=core; random) and Sediment depth (fixed). Because there was only 1 replicate of each Habitat $x$ Depth combination within each core, there is no test for the factor block or the interactions including the block factor in this analysis (Quinn \& Keough 2002).

Non-metric multidimensional scaling (nMDS; Clarke 1993) was used to illustrate the patterns of variability in macrobenthic invertebrate assemblages in invaded 
and native habitats within and between sites. For each estuary, differences in the composition of macrobenthic invertebrate assemblages between habitats and sites were investigated using analysis of similarities (ANOSIM) using the Bray-Curtis measure of similarity (Clarke 1993). Similarity percentage (SIMPER) analysis was used to determine the percentage contribution of each taxon to the Bray-Curtis measure of dissimilarity among habitats within sites, and within the same habitat between sites. We did not consider comparisons of different habitat types between sites to be relevant, so they were not compared. Two-factor ANOVAs (Habitat $\times$ Site) were then used to determine differences in the abundance of individual taxa that contributed $>75 \%$ of the dissimilarities among assemblages in the SIMPER analyses. Two-factor ANOVAs (Habitat $\times$ Site) were also used to determine differences in total faunal abundance, species richness, infaunal abundance, epifaunal abundance and the proportional representation of each of the 4 functional groups. We used proportional abundance of each feeding group to understand their relative abundance within assemblages.

For the ANOVAs, data were tested for homogeneity of variance using Cochran's test (Winer 1991) and transformed as appropriate. When transformations did not remove heterogeneity analysis proceeded as ANOVA is robust to deviations from heterogeneity when balanced designs are employed (Quinn \& Keough 2002). Tukey's tests were used to assess differences between habitats within sites when interaction terms were significant and when a significant difference was detected between habitats. Non-significant interaction terms in ANOVAs were removed if $p>0.25$ (Underwood 1997).

Because anoxia negatively affects many marine invertebrates and sediment redox potential differed among habitats in a reasonably consistent way across sites and estuaries (see 'Results'), correlations were used to explore relationships between redox potential and the 4 major macrobenthic invertebrate indicator categories: total abundance, species richness, infaunal abundance and epifaunal abundance. Because separate cores were used to collect redox potential and invertebrate data, we performed correlations using mean redox values and the invertebrate categories for each habitat at each site ( $\mathrm{N}=$ 7 habitat means for each analysis).

\section{RESULTS}

\section{Sediment properties and water quality}

Silt content was higher in areas with Caulerpa taxifolia compared to those with seagrass in Smiths Bay and at both sites in Burrill Lake, although differences were not statistically significant at Kings Point (Fig. 1A, D, Table 1). Silt content did not differ between seagrass and unvegetated sediment in St Georges Basin. Sediment redox potential was extremely reducing in all sediments. Redox potentials were lower in sediment with C. taxifolia compared to unvegetated sediments at Smiths Bay in St Georges Basin (Fig. 1B, Table 1) and lower in sediment with $C$. taxifolia compared to sediments with seagrasses in both estuaries (Fig. 1B, E, Table 1). There was no difference in sediment redox between Halophila ovalis and unvegetated sediment in Smiths Bay. Sediment $\mathrm{pH}$ was relatively neutral across all sites, but was significantly lower in areas with $C$. taxifolia and $H$. ovalis compared to those with unvegetated sediment in Pats Bay (Fig. 1C, Table 1), but not in Smiths Bay. Sediment $\mathrm{pH}$ was significantly higher in C. taxifolia compared to $H$. ovalis areas in Smiths Bay. All other habitat comparisons within sites in St Georges Basin were non-significant.
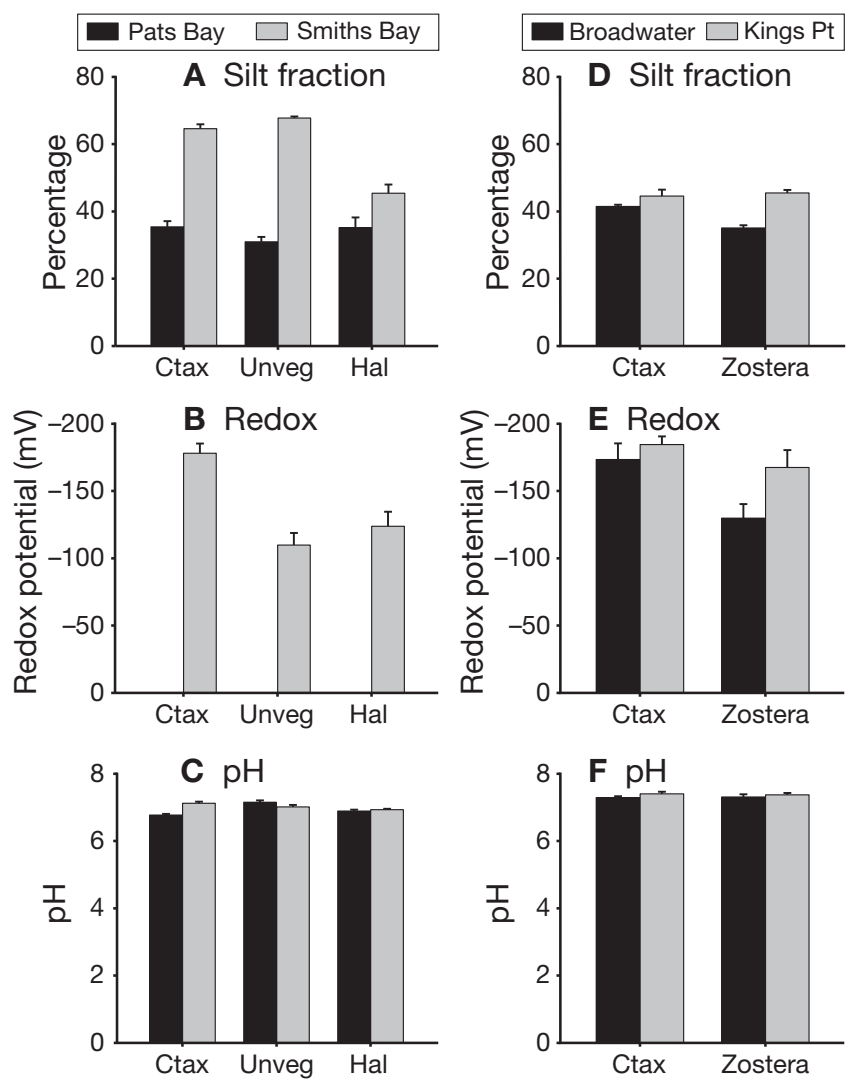

Fig. 1. Mean $( \pm \mathrm{SE})$ sediment silt fraction, redox and $\mathrm{pH}(\mathrm{N}=$ 5 habitat $^{-1}$ site $^{-1}$ ) in (A to C) Caulerpa taxifolia (Ctax), unvegetated sediment (Unveg) and Halophila ovalis (Hal) at Pats Bay and Smiths Bay, in St Georges Basin, and (D to F) C. taxifolia (Ctax) and Zostera capricorni (Zostera) at Broadwater and Kings Point, in Burrill Lake ( $\mathrm{N}=5$ cores habitat ${ }^{-1}$ site $^{-1}$ ). There were no data collected for redox potential at Pats Bay due to a malfunctioning probe 


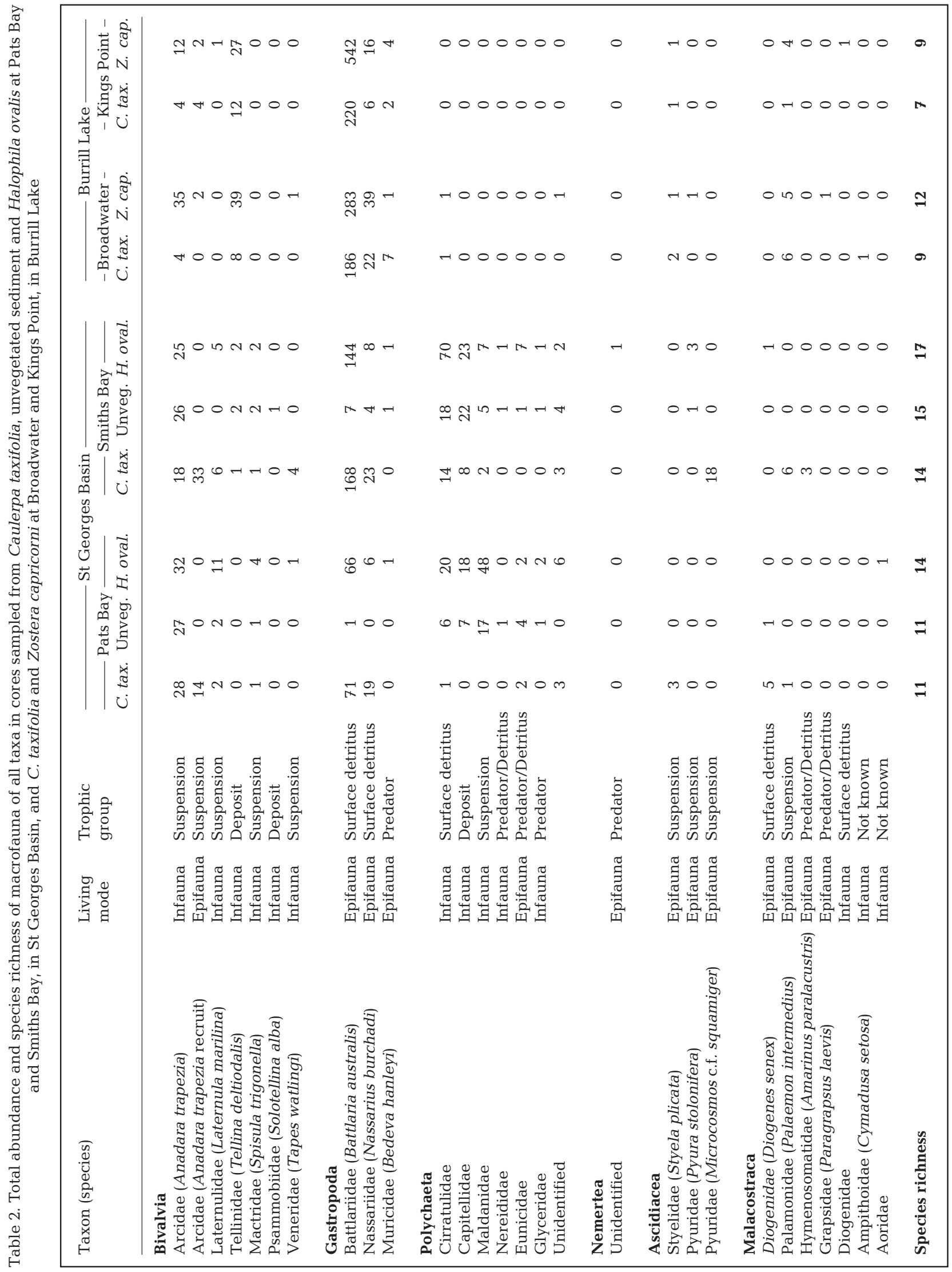




\begin{tabular}{|cccccc|}
\hline$\square$ & $\square$ & $\square$ & $\bigcirc$ & $\bigcirc$ & 0 \\
P-c & P-u & P-h & S-c & S-u & S-h \\
\hline
\end{tabular}

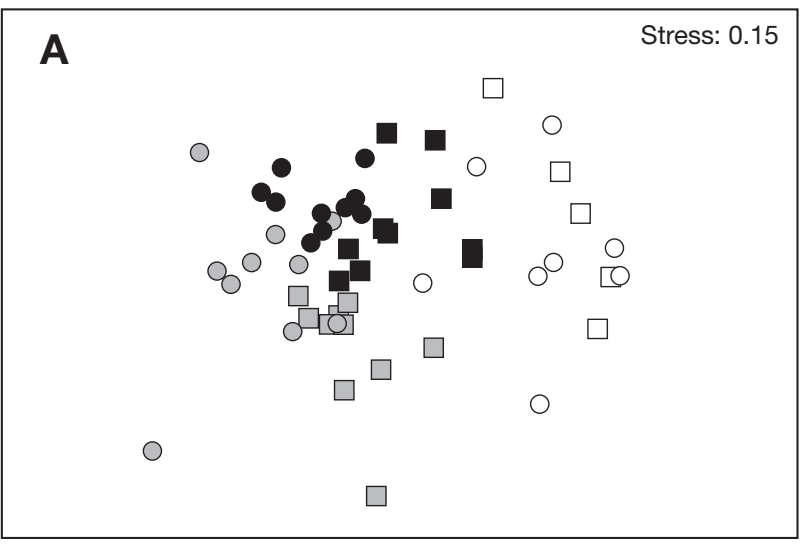

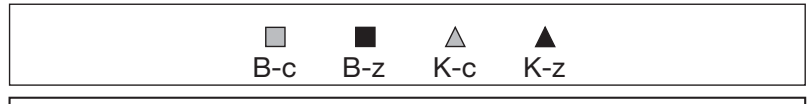

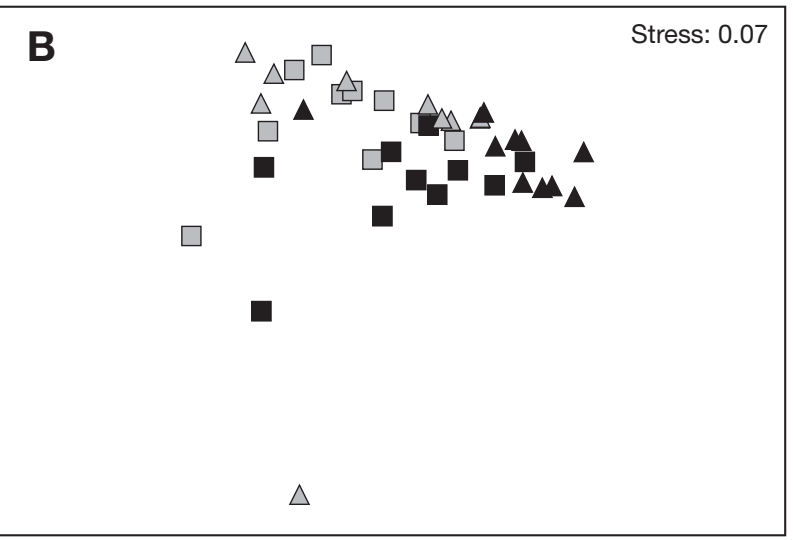

Fig. 2. nMDS plots illustrating patterns of difference of assemblages of invertebrates in different habitats and sites based on Bray-Curtis similarity on untransformed data $\left(\mathrm{N}=10\right.$ habitat $^{-1}$ site $\left.^{-1}\right)$. (A) St Georges Basin. P: Pats Bay site; S: Smiths Bay site; c: Caulerpa taxifolia; u: unvegetated sediment; h: Halophila ovalis. (B) Burrill Lake. B: Broadwater site; K: Kings Point site; c: C. taxifolia; z: Zostera capricorni

Table 3. Two-factor ANOVAs for the abundance of the taxa that contributed most to Bray-Curtis dissimilarities among assemblages in Halophila ovalis $(\mathrm{H})$, unvegetated sediment (U) and Caulerpa taxifolia (C) at Smiths Bay (SB) and Pats Bay (PB) in St Georges Basin, and C. taxifolia and Zostera capricorni (Z) at Broadwater (B) and Kings Point (KP) in Burrill Lake. Interaction terms for which $\mathrm{p}>0.25$ were removed from analyses. Only results of Tukey's tests examining differences between habitats are presented

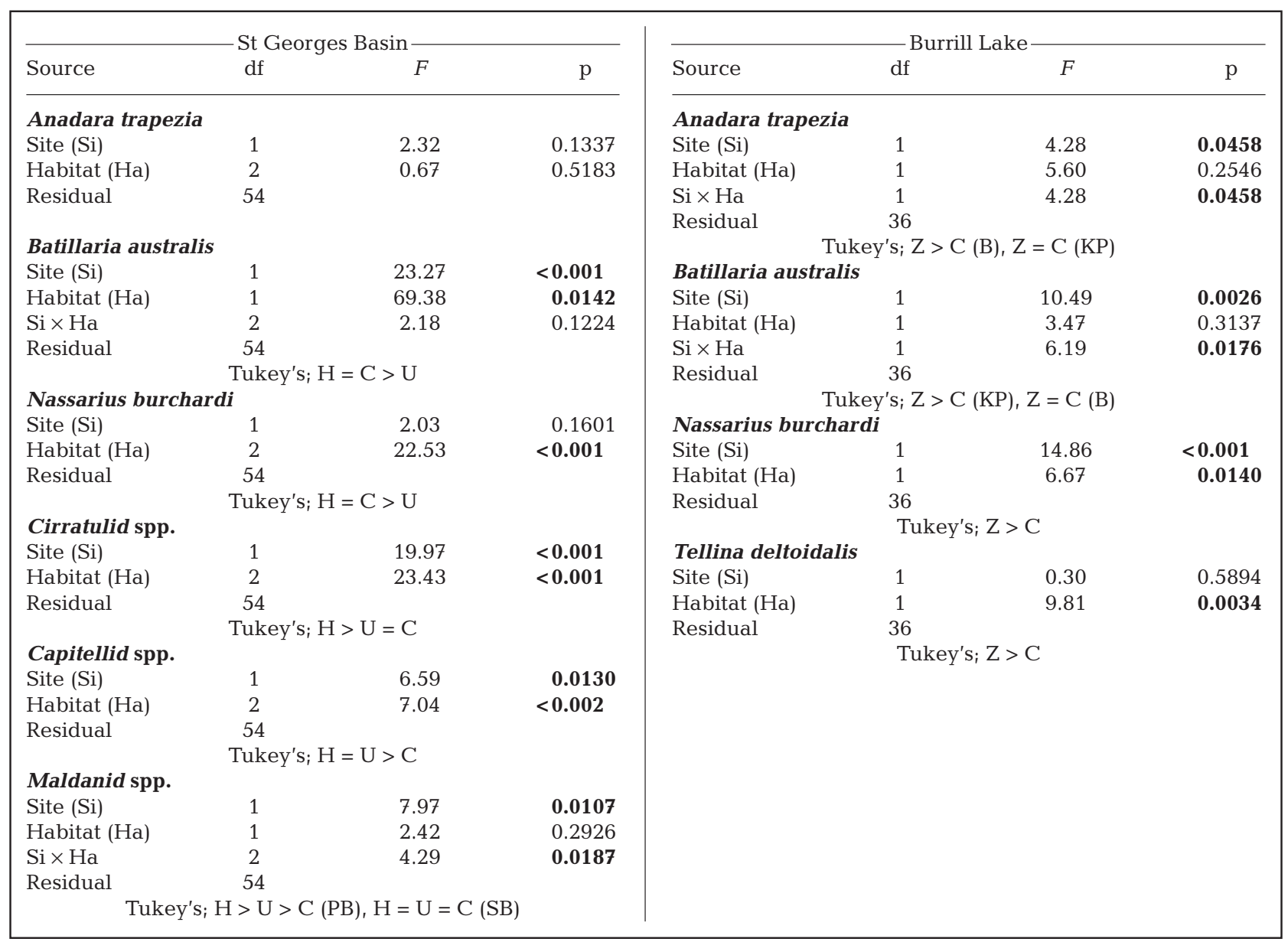


chaetes from the families Cirratulidae, Capitellidae and Maldanidae were less abundant in C. taxifolia areas compared to unvegetated sediments, although differences were not statistically significant for Cirratulidae (both sites) or Maldanidae (Smiths Bay; Table 3). In Burrill Lake, B. australis (Kings Point) and $N$. burchardi were significantly less abundant in areas with $C$. taxifolia compared to those with Zostera capricorni, as were the infaunal bivalves Anadara trapezia (Broadwater) and Tellina deltoidalis.

The total abundance of invertebrates was significantly higher in Caulerpa taxifolia and Halophila ovalis areas compared to unvegetated sediments, but there was no significant difference in total invertebrate abundances between areas with $C$. taxifolia and $H$. ovalis in St Georges Basin (Fig. 3A, Table 4). In Burrill Lake, total abundance of invertebrates was lower in $C$. taxifolia areas compared to those with Z Capricorni, although these differences were not significant (Fig. 3E, Table 4).

Species richness was significantly higher in areas with seagrass compared to those with Caulerpa taxifolia in both estuaries and higher in C. taxifolia areas compared to unvegetated sediments in St Georges Basin, although differences were not statistically significant (Fig. 3B, F, Table 4). Species richness was also significantly higher in seagrass compared to unvegetated sediments.

Infaunal abundance was significantly lower in Caulerpa taxifolia compared to unvegetated sediments in St Georges Basin (Fig. 3C, Table 4). In both estuaries, infaunal abundances were also lower in areas with C. taxifolia compared to those with seagrass although, at Kings Point, the difference between C. taxifolia and Zostera capricorni was not significant (Fig. 3C,G, Table 4). Infaunal polychaetes (St Georges Basin) and bivalves (Burrill Lake) occurred in notably lower densities in C. taxifolia areas (Table 2). Infaunal abundance was significantly higher in areas with Halophila ovalis compared to unvegetated sediments in St Georges Basin.

Epifaunal abundance was significantly higher in Caulerpa taxifolia and Halophila ovalis compared to unvegetated sediments, and significantly higher in $C$. taxifolia compared to in H. ovalis in St Georges Basin (Fig. 3D, Table 4). Epifaunal Anadara trapezia recruits, gastropods and 1 ascidian (at Smiths Bay) showed high abundances in areas with $C$. taxifolia (Table 2). By contrast, in Burrill Lake, epifaunal abundance was lower in C. taxifolia compared to Zostera capricorni at both sites, although differences were not statistically significant in Broadwater (Fig. $3 \mathrm{H}$, Table 4). Epifaunal gastropods occurred in high abundances in Z. capricorni.
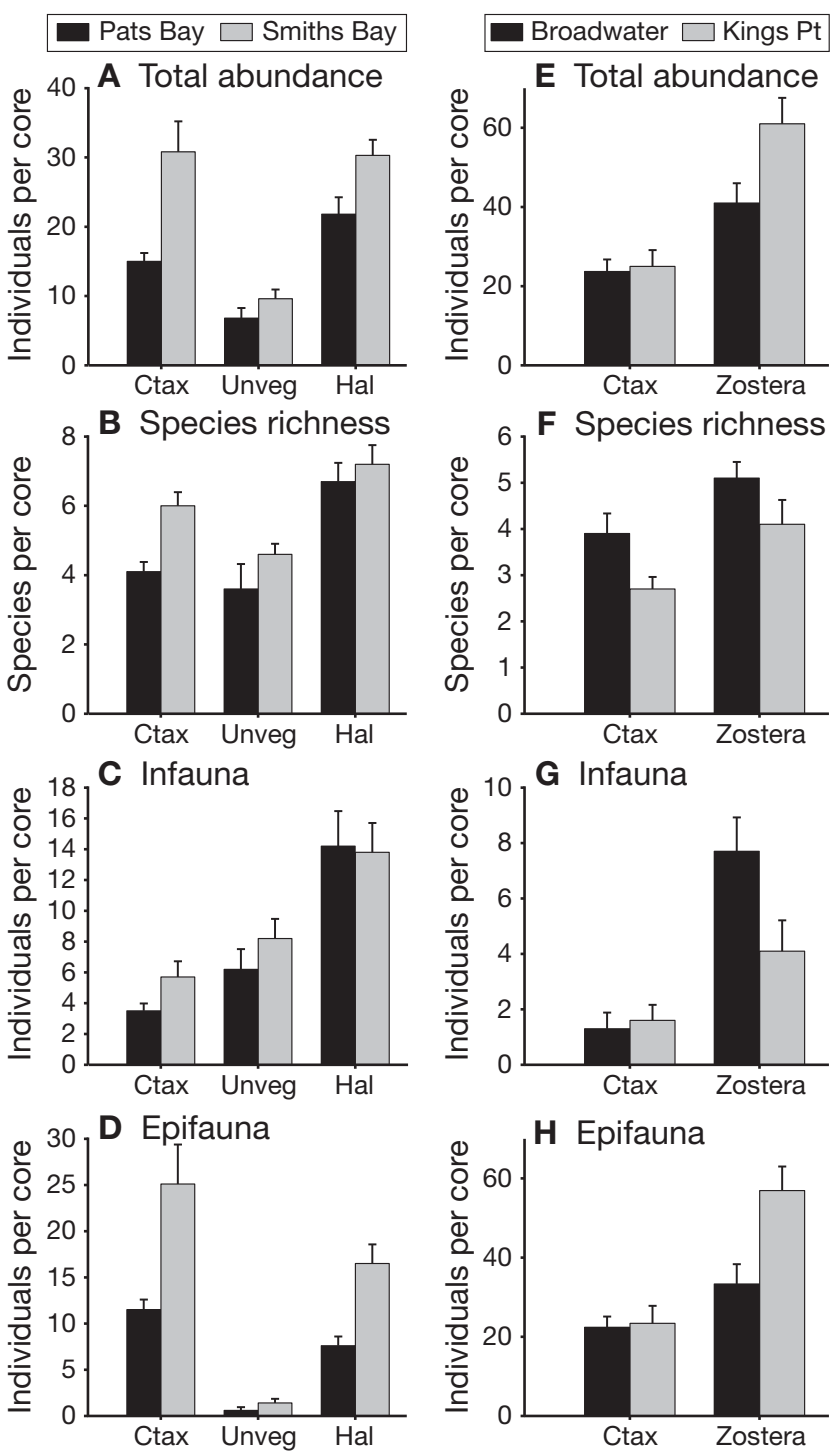

Fig. 3. Mean $( \pm \mathrm{SE})$ total abundance, species richness, infauna and epifauna core ${ }^{-1}$ in Caulerpa taxifolia (Ctax), unvegetated sediment (Unveg) and Halophila ovalis (Hal) at Pats Bay and Smiths Bay, in St Georges Basin (A to D), and C. taxifolia (Ctax) and Zostera capricorni (Zostera) at Broadwater and Kings Point, in Burrill Lake ( $\mathrm{E}$ to $\mathrm{H})(\mathrm{N}=10$ cores habitat ${ }^{-1}$ site $^{-1}$ )

\section{Functional groups}

Surface detritus feeding was the most common feeding mode observed in both estuaries (49.17 and $84.61 \%$ of all individuals in St Georges Basin and Burrill Lake, respectively).

The proportion of surface-feeding detritivores was significantly higher in Caulerpa taxifolia compared to unvegetated sediments in St Georges Basin (Fig. 4A, Table 5). In contrast, the proportional representations of suspension feeders, sub-surface deposit feeders and predators/omnivores were higher in unvegetated sedi- 
Table 4. Two-factor ANOVAs of total abundance, species richness (SR), infaunal abundance and epifaunal abundance in Halophila ovalis $(\mathrm{H})$, unvegetated sediment $(\mathrm{U})$ and Caulerpa taxifolia $(\mathrm{C})$ at Pats Bay (PB) and Smiths Bay (SB) in St Georges Basin, and unvegetated sediment, C. taxifolia and Zostera capricorni (Z) at Broadwater (B) and Kings Point (KP) in Burrill Lake. Interaction terms for which $p>0.25$ were removed from analyses. Only results of Tukey's tests examining differences between habitats are presented

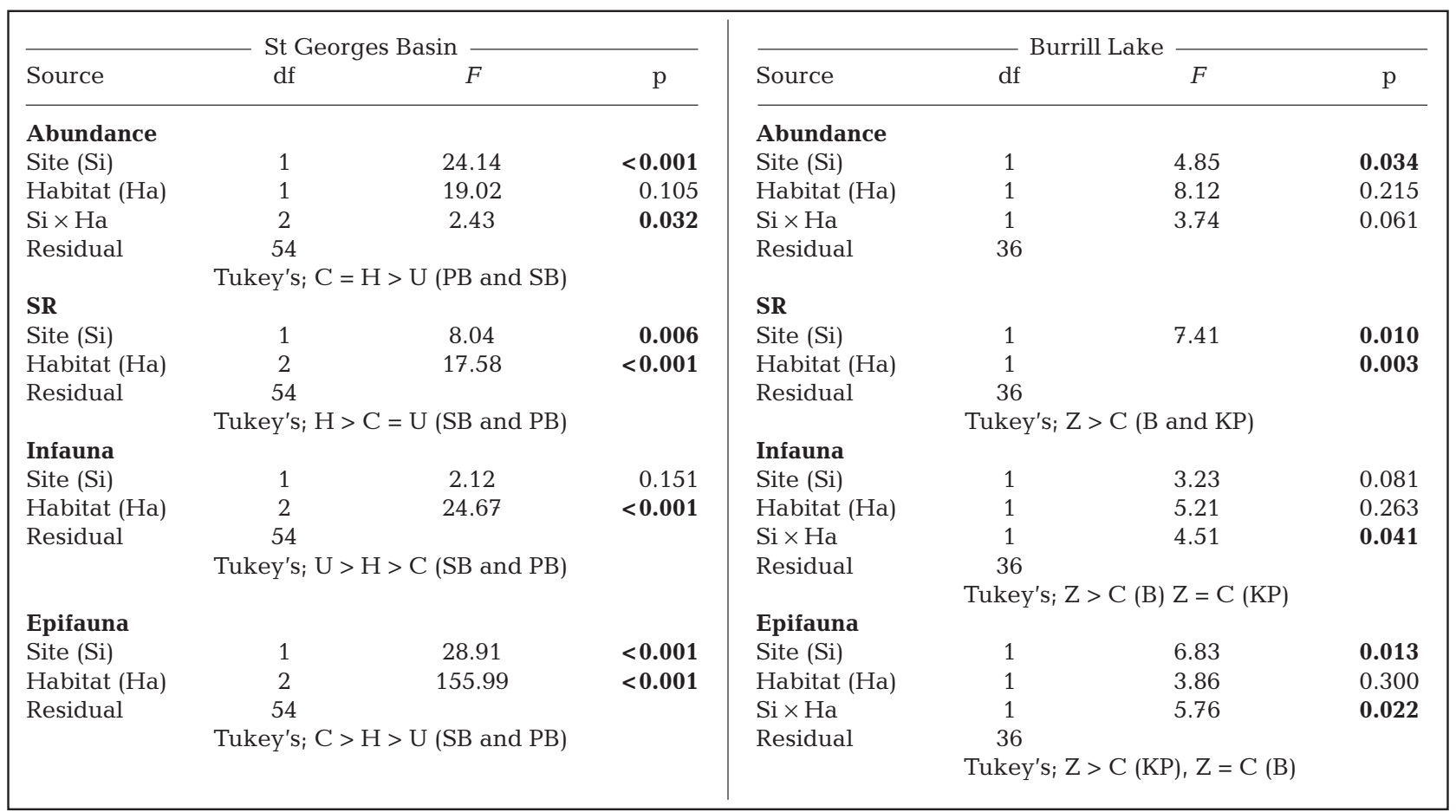

ment compared to areas with $C$. taxifolia, although differences between habitats were not significant (Fig. 4B to $\mathrm{D}$, Table 5). Similar non-significant patterns in the proportion of feeding groups were observed between Halophila ovalis and unvegetated sediment (Fig. 4A to D, Table 5). In both estuaries, the proportional representations of feeding groups in C. taxifolia and seagrasses were very similar (Fig. $4 \mathrm{~A}$ to $\mathrm{H}$, Table 5).

Habitats/sites with low average redox potential (e.g. the 3 Caulerpa taxifolia sites) had a significantly lower average abundance of infauna (Fig. 5). Relationships between redox potential and total abundance, species richness and epifauna were all non-significant (Fig. 5).

\section{DISCUSSION}

In line with our predictions, there were very different macroinvertebrate assemblages in areas with Caulerpa taxifolia, those with seagrass, and in unvegetated sediments. More specifically, when compared to unvegetated sediment, areas with $C$. taxifolia had a higher abundance of epifauna but a lower abundance of infauna and, when compared to seagrass, C. taxifolia areas also had a lower abundance of infauna, but the epifaunal response depended on the seagrass spe- cies or possibly the location. Epifaunal taxa were less abundant in areas with $C$. taxifolia compared to Zostera capricorni, but were more abundant in C. taxifolia compared to Halophila ovalis areas. The consistently lower infaunal abundances in C. taxifolia compared to those in all other habitats across multiple sites suggests that inhibition of infauna may be a general outcome of invasion by C. taxifolia. In contrast, differences in the response of epifaunal taxa suggest that general predictions will be difficult to make because their relative response may depend on the habitat $C$. taxifolia is being compared with (different seagrasses or unvegetated sediments).

The higher total and epifaunal abundance in Caulerpa taxifolia (and Halophila ovalis) areas compared to unvegetated sediments were due to the numerical dominance of the gastropods Battlaria australis and Nassarius burchardi. Although we only described patterns, possible mechanisms facilitating epifauna in areas with C. taxifolia compared to unvegetated sediments include decreased risk of predation, increased food supply, reduced physical stress and enhanced propagule supply and/or retention (Bruno \& Bertness 2001, Rodriguez 2006). The provision of a refuge from predation for fauna associated with invasive macrophytes has been widely reported (Crooks 

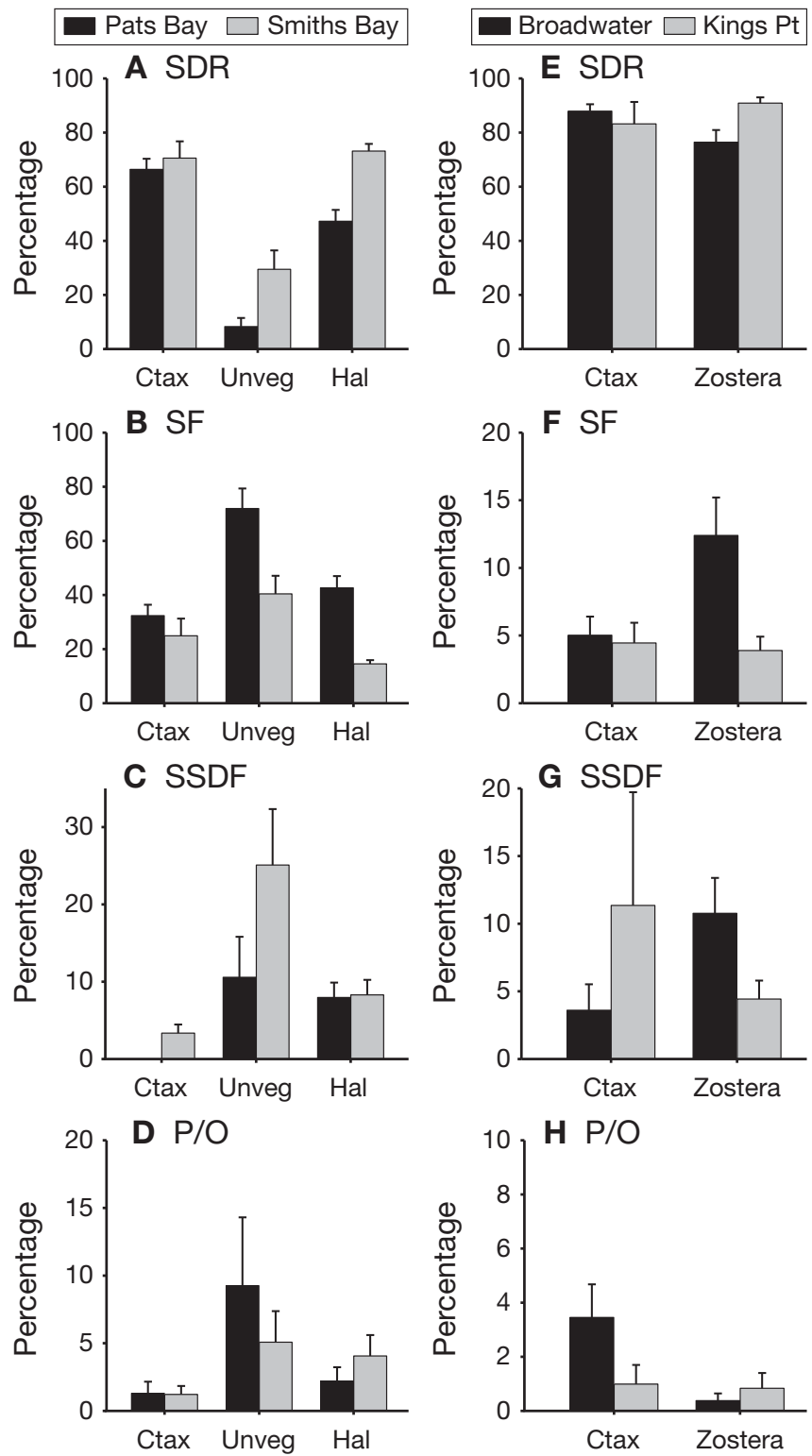

Fig. 4. Mean percentage $( \pm \mathrm{SE})$ representation of surface detritus feeders (SDR), suspension feeders (SF), sub-surface deposit feeders (SSDF) and predadors/omnivores (P/O) core $^{-1}$ in Caulerpa taxifolia (Ctax), unvegetated sediment (Unveg) and Halophila ovalis (Hal) at Pats Bay and Smiths Bay, in St Georges Basin (A to D), and C. taxifolia (Ctax) and Zostera capricorni (Zostera) at Broadwater and Kings Point, in Burrill Lake $(\mathrm{E}$ to $\mathrm{H})\left(\mathrm{N}=10\right.$ cores habitat ${ }^{-1}$ site $\left.^{-1}\right)$

2002, Rodriguez 2006). Indeed, Gribben \& Wright (2006a) found that C. taxifolia provided a refuge from predation for Anadara trapezia recruits. Alternatively, increased detrital food supply following invasion may be important. For example, invasion of a Spartinahybrid to an unvegetated tidal flat has positive effects on sub-surface deposit feeders that use Spartina detritus as a food resource (Neira et al. 2005, Levin et al.
2006). The relative importance of decreased predation or increased food supply may vary depending on the facilitated epifaunal species: increased detritus may be important for the epifaunal gastropods $B$. australis and $N$. burchardi, but not for $A$. trapezia recruits.

Differences in epifaunal abundance between Caulerpa taxifolia and native seagrasses also appeared to be driven by the relatively high abundance of the gastropods Battlaria australis and Nassarius burchadi in areas with $C$. taxifolia compared to those with Halophila ovalis, and a lower abundance of these 2 species in C. taxifolia compared to Zostera capricorni areas. Although we cannot directly compare epifaunal abundances between $H$. ovalis and $Z$. capricorni in the different estuaries, these differences may be related to differences in structural complexity or above- and below-ground biomass between the 2 seagrass species, both of which could influence predation and detrital food supply (Bruno \& Bertness 2001, Williams $\&$ Heck 2001). However, whether differences in epifaunal abundance between native seagrasses and $C$. taxifolia are related to differences in traits of the seagrasses or simply reflect differences between estuaries unrelated to seagrass species remains to be determined. For example, a potentially important factor not taken into account by our sampling is the amount of time $C$. taxifolia has been present at the different sites (5 yr at Burrill Lake vs. 2 yr at St Georges Basin). However, given that the traits of ecosystem engineers can have strong effects on facilitation (Bruno \& Bertness 2001, Gutierrez et al. 2003), and the mean abundance of epifauna in C. taxifolia was similar at 3 out of the 4 sites (Fig. 3), differences in traits between the seagrass species may explain the observed patterns of epifaunal abundance.

Despite the lower infaunal abundance in Caulerpa taxifolia areas compared to both unvegetated sediments and native seagrasses, there was no effect of habitat on the proportional representation of different infaunal functional groups (suspension feeders and sub-surface deposit feeders). This finding suggests that any impacts of $C$. taxifolia on infauna may not be restricted to specific functional groups, but may affect infauna generally. Indeed, the abundance of most polychaete and bivalve taxa were lower in areas with C. taxifolia compared to unvegetated sediments and habitats with native seagrasses in both estuaries, irrespective of feeding mode-even detritus- and/or deposit-feeding infauna (Cirratulidae and Tellina) occurred at lower abundances. Levin et al. (2006) and Neira et al. (2005) found lower abundances of surface-feeders, but no difference in sub-surface deposit feeders in sediments underlying the invasive Spartina-hybrid compared to nearby unvegetated tidal flats. 
Table 5. Two-factor ANOVAs of mean percentage representation of surface detritus feeders (SDR), suspension feeders (SF), subsurface deposit feeders (SSDF) and predators/omnivores (P/O) among Halophila ovalis (H), unvegetated sediment (U), Caulerpa taxifolia (C) at Pats Bay (PB) and Smiths Bay (SB) in St Georges Basin, and unvegetated sediment, C. taxifolia and Zostera capricorni (Z) at Broadwater (B) and Kings Point (KP) in Burrill Lake. Interaction terms for which p $>0.25$ were removed from analyses.

Only results of Tukey's tests examining differences between habitats are presented

\begin{tabular}{|c|c|c|c|c|c|c|c|}
\hline \multirow[b]{2}{*}{ Source } & \multicolumn{3}{|c|}{ St Georges Basin } & \multirow[b]{2}{*}{ Source } & \multirow{2}{*}{$\overline{\mathrm{df}}$} & \multirow[b]{2}{*}{$F$} & \multirow[b]{2}{*}{$\mathrm{p}$} \\
\hline & $\mathrm{df}$ & $F$ & $\mathrm{p}$ & & & & \\
\hline SDR & & & & SDR & & & \\
\hline Site (Si) & 1 & 19.29 & $<0.001$ & Site (Si) & 1 & 0.04 & 0.841 \\
\hline Habitat (Ha) & 2 & 21.71 & 0.044 & Habitat (Ha) & 1 & 0.01 & 0.947 \\
\hline $\mathrm{Si} \times \mathrm{Ha}$ & 2 & 2.86 & 0.066 & $\mathrm{Si} \times \mathrm{Ha}$ & 1 & 2.85 & 0.100 \\
\hline Residual & \multicolumn{3}{|c|}{ Tukey's; C = H > U } & Residual & 36 & & \\
\hline SF & & & & SF & & & \\
\hline Site (Si) & 1 & 25.44 & $<0.001$ & Site (Si) & 1 & 6.02 & 0.019 \\
\hline Habitat (Ha) & 2 & 5.98 & 0.143 & Habitat (Ha) & 1 & 0.97 & 0.505 \\
\hline $\mathrm{Si} \times \mathrm{Ha}$ & 2 & 2.87 & 0.065 & $\mathrm{Si} \times \mathrm{Ha}$ & 1 & 3.40 & 0.074 \\
\hline Residual & 54 & & & Residual & 36 & & \\
\hline SSDF & & & & SSDF & & & \\
\hline Site (Si) & 1 & 9.05 & 0.004 & Site (Si) & 1 & 0.41 & 0.528 \\
\hline Habitat (Ha) & 2 & 5.81 & 0.147 & Habitat (Ha) & 1 & 0.98 & 0.503 \\
\hline $\mathrm{Si} \times \mathrm{Ha}$ & 2 & 1.64 & 0.203 & $\mathrm{Si} \times \mathrm{Ha}$ & 1 & 3.58 & 0.067 \\
\hline Residual & 54 & & & Residual & 36 & & \\
\hline $\mathrm{P} / \mathrm{O}$ & & & & $\mathrm{P} / \mathrm{O}$ & & & \\
\hline Site (Si) & 1 & 0.23 & 0.636 & Site (Si) & 1 & 1.71 & 0.199 \\
\hline Habitat (Ha) & 2 & 1.99 & 0.147 & Habitat (Ha) & 1 & 1.09 & 0.486 \\
\hline \multirow[t]{2}{*}{ Residual } & 54 & & & $\mathrm{Si} \times \mathrm{Ha}$ & 1 & 3.26 & 0.080 \\
\hline & & & & Residual & 36 & & \\
\hline
\end{tabular}
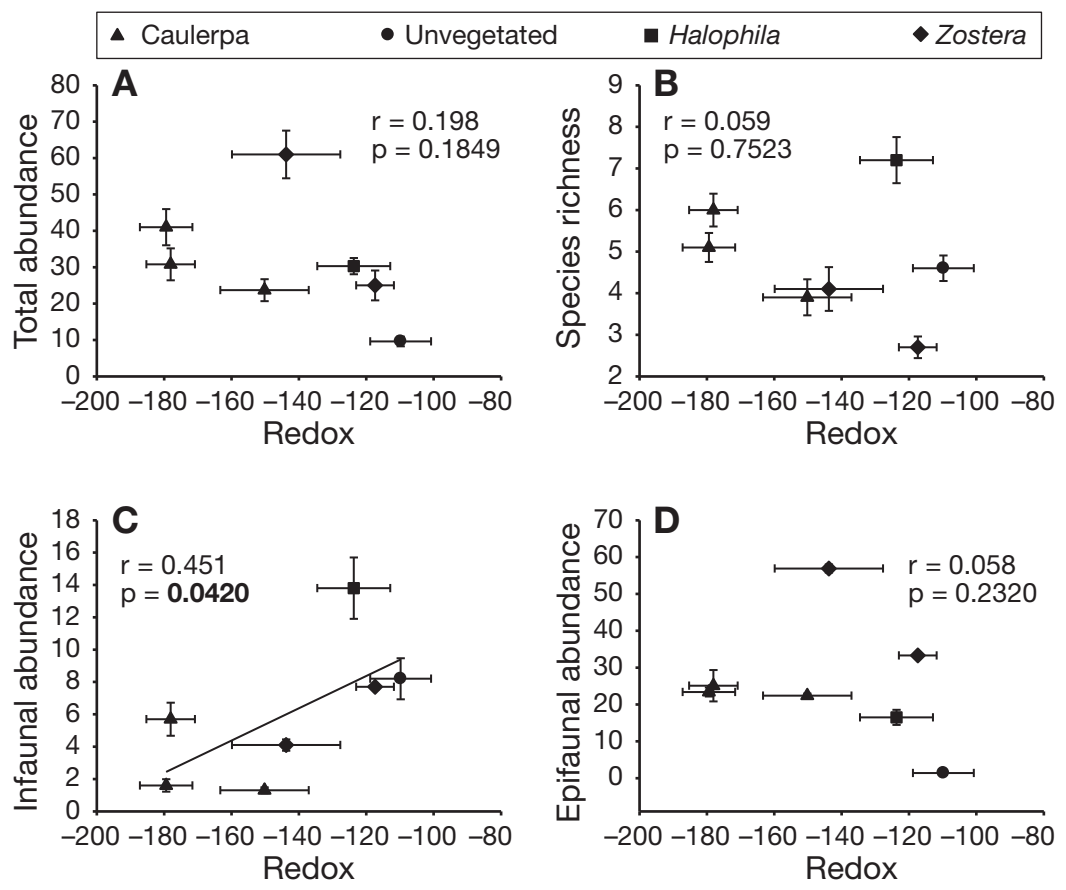

Fig. 5. Correlations between mean redox potential and mean (A) total invertebrate abundance, (B) species richness, (C) infaunal abundance and (D) epifaunal abundance per core in all habitats sampled at Smiths Bay, in St Georges Basin, and Broadwater and Kings Point, in Burrill Lake
The lower densities of infauna in Caulerpa taxifolia may be related to changes in environmental characteristics following invasion. In the present study, redox potential varied consistently among habitats (i.e. unvegetated $>$ Halophila ovalis $>$ C. taxifolia, Zostera capricorni $>$ C. taxifolia), and the correlation between mean redox potential and mean infaunal abundance indicated that redox potential may be a strong structuring force among habitats at large spatial scales. Anoxia or hypoxia, resulting from reduced redox potential, has demonstrated negative effects on infauna (Shumway \& Scott 1993, Laudien et al. 2002). Neira et al. (2006) showed that reduced water flow associated with the establishment of hybrid Spartina patches promoted the deposition of fine-grained, organic-rich sediments, which resulted in an increase in pore water sulfur and anoxia. Reduced flow, increased anoxia and increased levels of hydrogen sulphide (Chisholm \& Moulin 2003, Gribben et al. 2009) have 
also been recorded in C. taxifolia habitats compared to unvegetated sediments. In addition, low DO in the water column within the C. taxifolia canopy compared to unvegetated sediments (Gribben et al. 2009) may also contribute to the low abundance of surface-feeding infauna. The reasons for differences in infaunal composition between $C$. taxifolia and native seagrasses are less clear, but may also be linked to differences in anoxia, hydrogen sulphide, or the degree of structural complexity of $C$. taxifolia habitats versus seagrasses and its subsequent effects on flow regimes, sediment quality, DO and food supply. The mechanisms of how C. taxifolia and other habitat-forming invasive species affect infauna remain to be determined experimentally.

Despite the differences in community structure among habitats, the total abundance, species richness, and abundance of infauna and epifauna in Caulerpa taxifolia areas were very similar across sites and estuaries (Fig. 2). Multivariate analyses also indicated no differences in assemblages within C. taxifolia habitats between sites in Burrill Lake and the lowest differences for assemblages in C. taxifolia habitats between sites in St Georges Basin. Neira et al. (2005) present similar data, showing a reasonably consistent number of individuals and species per core in Spartina-hybrids at different sites, despite large differences in the same parameters in uninvaded habitats between sites. Homogenisation of communities in soft-sediment marine habitat-forming invasive species across large spatial scales may result from the strong consistent effects that these species have on environmental factors such as water flow and sediment quality. The potential effect of habitat-forming invasive species in decreasing ecological variation in assemblages at large scales is an important avenue for future research.

Our findings are consistent with invasion by Caulerpa taxifolia causing important changes in softsediment macroinvertebrate assemblages. The low abundance of infauna compared to that in unvegetated sediment and native vegetated habitats is similar to results for several other habitat-forming invasive species of soft sediments (Neira et al. 2005, Levin et al. 2006), although other species show positive effects on infaunal abundance (Posey 1988). Thus, generalisations about changes associated with the invasion of marine habitat-forming species may be difficult to make. Overall, our conclusions are tempered, as we have no information on macrofaunal assemblages at these sites before the invasion of C. taxifolia, nor have we determined effects using manipulative experiments. We have simply described patterns inside and outside of invaded areas. Future work should focus on experimental manipulations of $C$. taxifolia to deter- mine if it is indeed causing the observed changes in macrofaunal assemblages. Moreover, manipulations of abiotic factors potentially affecting macroinvertebrate survivorship (sediment properties, water quality, food supply, larval supply and predator activity) will be important in identifying mechanisms causing impacts (e.g. Neira et al. 2006).

Acknowledgements. We are grateful to Mark Meyer and Shannon Collier for help in the field, Peter Barnes (University of Wollongong) and Roger Springthorpe (Australian Museum) for help with species identification, and Mark O'Donnell and Jose Abrantis (University of Wollongong) for help with water quality and sediment grain size analyses.

\section{LITERATURE CITED}

Anderson LW (2005) California's reaction to Caulerpa taxifolia: a model for invasive species rapid response. Biol Invasions 7:1003-1006

Bruno JF, Bertness MD (2001) Habitat modification and facilitation in benthic marine communities. In: Bertness $M$, Gaines S, Hay M (eds) Marine community ecology. Sinuaer Associates Inc., Sunderland, MA, p 201-218

> Ceccherelli G, Cinelli F (1997) Short-term effects of nutrient enrichment of the sediment and interactions between the seagrass Cymedocea nodosa and the introduced green alga Caulerpa taxifolia in a Mediterranean bay. J Exp Mar Biol Ecol 217:165-177

Ceccherelli G, Sechi N (2002) Nutrient availability in the sediment and the reciprocal effects between the native seagrass Cymodocea nodosa and the introduced rhizophytic alga Caulerpa taxifolia. Hydrobiologia 474:57-66

Chisholm JRM, Moulin P (2003) Stimulation of nitrogen fixation in refractory organic sediments by Caulerpa taxifolia (Chlorophyta). Limnol Oceanogr 48:787-794

Clarke KR (1993) Non-parametric multivariate analyses of changes in community structure. Aust J Ecol 18:117-143

Creese RG, Davis AR, Glasby TM (2004) Eradicating and preventing the spread of the invasive alga Caulerpa taxifolia in NSW. NSW Fisheries Final Report Ser 64

Crooks JA (1998) Habitat alteration and community-level effects of an exotic mussel, Musculista senhousia. Mar Ecol Prog Ser 162:137-152

Crooks JA (2002) Characterizing eco-system consequences of biological invasions: the role of ecosystem engineers. Oikos 97:153-166

Crooks JA, Khim HS (1999) Architectural vs. biological effects of a habitat-altering, exotic mussel, Musculista senhousia. J Exp Mar Biol Ecol 240:53-75

Edgar GJ (2000) Australian marine life: the plants and animals of temperate waters. Reed New Holland, Sydney

Fauchald K, Jumars P (1979) The diet of worms; a study of polychaete feeding guilds. Oceanogr Mar Biol Annu Rev 17:193-284

Gale SJ, Hoare PG (1991) Quaternary sediments: petrographic methods for the study of unlithified rocks. Belhaven, London

Glasby TM, Creese RG (2007). Invasive marine species management and research. In: Connell SD, Gillanders BM (eds) Marine ecology. Oxford University Press, Melbourne, p 569-594

Gribben PE, Wright JT (2006a) Invasive seaweed enhances 
recruitment of a native bivalve: roles of refuge from predation and habitat choice. Mar Ecol Prog Ser 318: $177-185$

Gribben PE, Wright JT (2006b) Sublethal effects on reproduction in native fauna: Are females more vulnerable to biological invasion? Oecologia 149:352-361

Gribben PE, Wright JT, O'Connor W, Doblin M, Eyre B, Steinberg PD (2009) Reduced performance of native infauna following recruitment to a habitat-forming invasive marine alga. Oecologia 158:733-745

Gutierrez JL, Jones CG, Strayer DL, Iribarne OO (2003) Mollusks as ecosystem engineers: the role of shell production in aquatic habitats. Oikos 101:79-90

Hacker SN, Dethier MN (2006) Community modification by a grass invader has differing impacts for marine habitats. Oikos 113:279-286

Hedge P, Kriwoken LK (2000) Evidence for effects of Spartina anglica invasion on benthic macrofauna in Little Swanport Estuary, Tasmania. Austral Ecol 25:150-159

Laudien J, Schiedek D, Brey T, Portner H-O, Arntz WE (2002) Survivorship of juvenile surf clams Donax serra (Bivalvia, Donacidae) exposed to severe hypoxia and hydrogen sulphide. J Exp Mar Biol Ecol 271:9-23

Levin LA, Neira C, Grosholz ED (2006) Invasive cordgrass modifies wetland trophic function. Ecology 87:419-432

Lowe S, Browne M, Boudjelas S, De Poorter M (2000) 100 of the world's worst invasive alien species. ICUN, Gland. Available at: www.issg.org/booklet.pdf

Meinesz A, Belsher T, Thibaut T, Antolic B, and others (2001) The introduced marine alga Caulerpa taxifolia in the Medtiterranean. Biol Inv 38:499-508

> Neira C, Levin LA, Grosholz ED (2005) Benthic macrofaunal communities of three sites in San Francisco Bay invaded by hybrid Spartina, with comparison to uninvaded habitats. Mar Ecol Prog Ser 292:111-126

Neira C, Grosholz ED, Levin LA, Blake R (2006) Mechanisms generating modification of benthos following tidal flat invasion by a Spartina hybrid. Ecol Appl 16:1391-1404

Posey MH (1988) Community changes associated with the

Editorial responsibility: Laura Airoldi,

Ravenna, Italy spread of an introduced seagrass, Zostera japonica. Ecology 69:974-983

Quinn GP, Keough MJ (2002) Experimental design and data analysis for biologists. University Press, Cambridge

$>$ Reusch TBH, Williams SL (1999) Macrophyte canopy structure and the success of an invasive marine bivalve. Oikos 84:398-416

Rodriguez LF (2006) Can invasive species facilitate native species? Evidence of how, when, and why these impacts occur. Biol Invasions 8:927-939

Shumway SE, Scott TM (1993) The effects on anoxia and hydrogen sulphide on survival, activity and metabolic rate in the coot clam, Mulinia lateralis (Say). J Exp Mar Biol Ecol 71:135-146

Underwood AJ (1997) Experiments in ecology. Cambridge University Press, Cambridge

Williams SL, Heck KLJ (2001) Seagrass community ecology. In: Bertness MD, Gaines SD, Hay ME (eds) Marine community ecology. Sinuaer Associates, Sunderland, MA, p 317-338

Winer BJ (1991) Statistical principles in experimental design. McGraw-Hill, New York

> Wright JT (2005) Differences between native and invasive Caulerpa taxifolia: a link between asexual fragmentation and abundance in invasive populations. Mar Biol 147: 559-569

- Wright JT, Davis AR (2006) Demographic feedback between clonal growth and fragmentation in an invasive seaweed. Ecology 87:1744-1754

Wright JT, Gribben PE (2008) Predicting the impact of an invasive seaweed on the fitness of native fauna. J Appl Ecol 45:1540-1549

Wright JT, McKenzie LA, Gribben PE (2007) A decline in the density and health of a native bivalve associated with Caulerpa taxifolia invasion. Mar Freshw Res 58:263-277

> York PH, Booth DJ, Glasby TM, Pease BC (2006) Fish assemblages in habitats dominated by Caulerpa taxifolia and native seagrasses in south-eastern Australia. Mar Ecol Prog Ser 312:223-234

Submitted: March 25, 2008; Accepted: January 12, 2009 Proofs received from author(s): March 27, 2009 